\title{
Skin and soft tissue infections in hospitalized cancer patients
}

\author{
A retrospective study
}

Huda M. Al-Mutairi, PharmD, MSc, Oluwaseun Egunsola, MD, PhD, Afaf Almutairi, MD, Salha M. Al-Dossary, MSc, Rana S. Alshammasi, BPharm, Dalal S. Al-Dossari, MSc, Sheraz Ali, PharmD, MPH, PhD Sch.

\begin{abstract}
الأهداف : تقييم الخصائص السريرية والوبائية لمرضى السرطان في المستشفيات

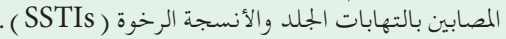

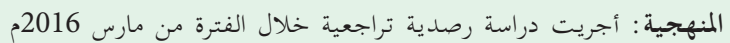

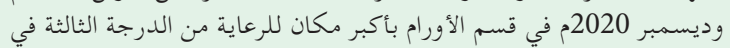

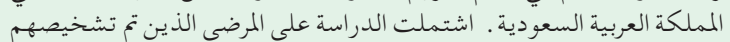
كمضاعفات معقدة وغير معقدة .

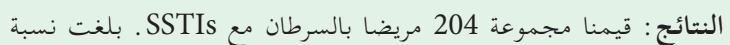

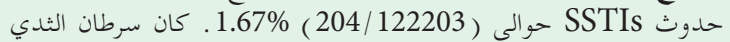

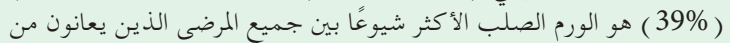

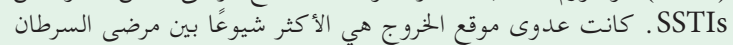

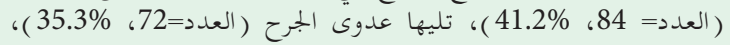

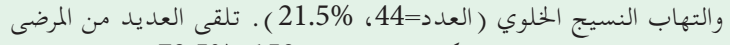

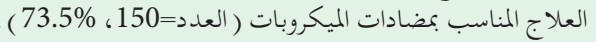

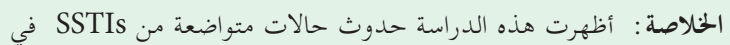

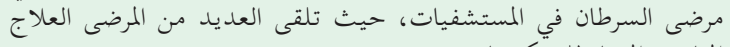
المناسب المضاد للميكروبات في المبتشيات
\end{abstract}

Objectives: To assess the clinical and epidemiological characteristics of hospitalized cancer patients with skin and soft-tissue infections (SSTIs).

Methods: An observational retrospective study was conducted between March 2016 and December 2020 at the Oncology Department of King Saudi Medical City, Riyadh, Saudi Arabia. Patients with complicated and uncomplicated SSTIs were included.

Results: A total of 204 cancer patients with SSTIs were evaluated. The incidence of SSTIs was $1.67 \%$ $(204 / 12,203)$. Breast cancer $(39 \%)$ was the most common solid tumor in all patients with SSTIs. Exit site infection $(\mathrm{n}=84,41.2 \%)$ was the most common SSTI in cancer patients, followed by wound infection $(\mathrm{n}=72,35.3 \%)$, and cellulitis $(\mathrm{n}=44,21.5 \%)$. The majority of patients received appropriate antimicrobial therapy $(\mathrm{n}=150,73.5 \%)$.
Conclusion: This study has shown a modest incidence of SSTIs in hospitalized cancer patients, with many of the patients received appropriate antimicrobial therapy.

Keywords: Solid tumor, SSTI, infection, antibiotic, cancer

Saudi Med J 2021; Vol. 42 (12): 1333-1340 doi: 10.15537/smj.2021.42.12.20210624

From the Pharmaceutical Care Services (Al-Mutairi, Alshammasi, Al-Dossary S, Al-Dossari D), from the Internal Medicine Department (Almutairi), King Saud Medical City, Ministry of Health, Riyadh, Kingdom of Saudi Arabia; from the Department of Community Health Sciences (Egunsola), University of Calgary, Canada; and from the School of Pharmacy and Pharmacology (Ali), University of Tasmania, Sandy Bay, Australia.

Received 5th August 2021. Accepted 2nd November 2021.

Address correspondence and reprint request to: Dr. Sheraz Ali, School of Pharmacy and Pharmacology, University of Tasmania, Hobart, Australia.E-mail:sheraz.ali@utas.edu.au

ORCID ID: https://orcid.org/0000-0001-9557-0345

$\mathrm{D}$ espite advances in the management of infectious complications in oncology patients, infections remain one of the most significant causes of morbidity and mortality. ${ }^{1}$ In addition, they may delay the provision of the scheduled chemotherapy, thus decreasing the survival rate of cancer patients. ${ }^{1}$ A set of commonly observed infections posing diagnostic and therapeutic challenges to cancer patients are skin and soft-tissue infections (SSTIs).

Skin and soft-tissue infections may affect any part of the body and are prevalent (69\%) in the hospitalized cancer patients. ${ }^{2}$ The SSTIs comprise a wide variety of clinical conditions that involve the skin and underlying subcutaneous tissue, fascia, or muscle. These may vary 
in severity from simple superficial infections to severe necrotizing infections (Table 1). ${ }^{3-5}$ Some of the common complicated and uncomplicated SSTIs includes infected ulcers, infected burns, impetigo, furuncles, necrotizing fasciitis, cellulitis, erysipelas, skin abscess, and ecthyma gangrenosum. ${ }^{2,4}$

Skin and soft-tissue infections embody a diagnostic challenge in the cancer patients particularly due to missing etiologic diagnosis and difficulty in assessing the severity. ${ }^{1}$ The spread of systematic disease to the skin may also lead to the occurrence of SSTIs. ${ }^{6-8}$ Several factors are associated with SSTIs in patients with solid tumors such as preceding antimicrobial therapy, prior blood transfusion, recent chemotherapy, and prior invasive procedures. ${ }^{7,8}$ Despite this, SSTIs can be managed successfully through prompt recognition, rational use of antibiotics, and timely surgical drainage. ${ }^{4}$ The treatment adopted however depends on the types of SSTIs. For example, a simple abscess should be treated through incision and drainage, while antibiotics are indicated for complicated SSTIs. ${ }^{4}$ Therefore, timely recognition and immediate provision of appropriate empirical antibiotic therapy are vital, particularly in neutropenic patient. ${ }^{7,8}$

Early and appropriate management of infection in cancer patients is essential for optimizing patient outcomes. However, the role of antibiotic treatment of SSTIs is still poorly understood and not well-supported through the scientific evidence. ${ }^{1}$ Previous study has reported the use of inappropriate antibiotics for the treatment of immunocompetent patients. ${ }^{9}$ The impact of the provision of an inappropriate antimicrobial treatment in cancer patients is also lacking in the literature, as prolonged infection can also delay antitumor therapy. ${ }^{10}$ The rates of resistance has also been found to be higher among the prescribed antibiotics in cancer patients. ${ }^{11}$ Given the high rates of the morbidity and mortality due to SSTIs, ${ }^{1}$ it is crucial to understand the characteristics of these infections to improve the quality of care. In the Kingdom of Saudi Arabia (KSA), there is a dearth of data regarding SSTIs and their management in immunosuppressed cancer patients and those with neutropenia. Therefore, we aimed to explore the clinical and epidemiological characteristics of hospitalized cancer patients with skin and soft tissue infections.

Disclosure. Authors have no conflict of interests, and the work was not supported or funded by any drug company.
Table 1 - United States Food and Drug Administration classifications of skin and soft-tissue infections (SSTIs). ${ }^{4}$

\begin{tabular}{l}
\hline Classifications \\
\hline Types of SSTIs \\
Complicated SSTIs \\
Uncomplicated SSTIs \\
Conditions for classifying patients with SSTIs \\
Clinical condition of the patient \\
Anatomical extension \\
Characteristics of the infection \\
Purulent SSTIs or not purulent SSTIs \\
$\quad$ Necrotizing SSTIs or non-necrotizing SSTIs \\
\hline
\end{tabular}

Methods. This was an observational retrospective study of patients receiving treatment at the Oncology Department of the King Saud Medical City, Riyadh, $\mathrm{KSA}$, one of the largest government hospital in KSA, between March 2016 and December 2020. This setting serves a broad range of patients and many of them present with complicated medical problems.

Patients with a diagnosis of complicated and uncomplicated SSTIs were included. The exclusion criterion is the absence of clinical information.

A SSTI is defined as "a clinical entity of variable presentation, etiology, and severity that involve microbial invasion of the layers of the skin and underlying soft tissues." 12

Patients' response status to antitumor therapy after the SSTI episodes' date of onset were classed as complete response, partial response, stable disease, or progressive disease. The definition of neutropenia was in conformity with the National Cancer Institute common toxicity criteria, version $2.0 .^{13}$ The empirical antibiotic therapy was deemed appropriate if the organism isolated from the affected area is predisposed to at least one of the antibiotics prescribed. Appropriate was defined as an antibiotic to which a bacterial isolate was sensitive, whereas inappropriate antibiotic therapy was defined as the prescribing of an antibiotic for treating an insensitive bacteria. ${ }^{9}$

Data was collected from the patient files and the hospital's electronic health records. Clinical and demographic information including age, gender, underlying malignancy, type of SSTI, site of infection, signs and symptoms, blood transfusions, medications, exposure to radiotherapy or chemotherapy (during the previous thirty days), the status of neoplastic disease (complete response, partial response, stable disease, or progressive disease), performance status, treatment with an invasive procedure (during the preceding 10 
days), SSTI episodes' date of onset, date of preceding admission, presence of fever, signs of localized infection along with antibiotic given for every episode were extracted and recorded on a data collection sheets. Laboratory investigations including the results of all relevant cultures, the source and type of isolated microorganisms, and their susceptibility patterns were also recorded.

An ethics approval was provided by the Research Ethics Department of the King Saud Medical City (Approval number: H1RI-05-Jan21-01) for using cancer patients' de-identified demographic, clinical and medication data. A waiver of individual patient consent was granted by the Research Ethics Department of the King Saud Medical City, Riyadh, KSA. All data for this research project was de-identified and patient-specific information was not available. This study was performed as per the principles of the Declaration of Helsinki.

Statistical analysis. Data analysis was descriptive. No inferential statistics was conducted.

Results. Of the 12,203 patients admitted at the Oncology department during the study period, 204 were cancer patients with SSTIs (incidence, 1.67\%). The mean patient's age was 49.9 (19.2) years, and the mean weight was $61.6(10.2) \mathrm{kg}$ (Table 2). One hundred and twenty-eight $(62.4 \%)$ of the patients were female, $60.9 \%$ of whom were receiving treatment for breast cancer. In total, breast cancer accounted for $38 \%$ of solid tumors in all patients. Other common solid tumors were colorectal carcinoma $(\mathrm{n}=33,16 \%)$ and lymphoma $\mathrm{n}=22$, $10.7 \%)$. Approximately $80 \%$ of all the patients had a fever, one-quarter had co-existing diabetes mellitus, 3 quarters had a recent chemotherapy and a previous invasive procedure respectively; while $10 \%$ had received a recent blood transfusion or radiotherapy, respectively. Approximately one-third developed diabetes post chemotherapy $(35 \%)$ and were taking antimicrotubular $(32.4 \%)$ such as paclitaxel (18.9\%) and docetaxel $(14.7 \%)$ as their chemotherapeutic regimen. Over 37\% of the regimens were being taken weekly. A total of 22 patients were taking the chemotherapies in 2 and 15 patients were taking 6 cycles. The SSTIs included, exit site infections $(\mathrm{n}=84,41.2 \%)$, wound infections $(\mathrm{n}=72$, $35.3 \%)$, cellulitis $(n=44,21.6 \%)$, and abscesses $(n=4$, 2\%) (Figure 1 and Table 3).

Staphylococcus aureus was the most commonly cultured organism $(\mathrm{n}=35,17.2 \%)$, others included: Escherichia coli $(\mathrm{n}=24,11.8 \%)$ and pseudomonas aeruginosa ( $\mathrm{n}=18,8.8 \%)$ (Figure 2$)$. One hundred and thirty-two patients $(64.7 \%)$ had positive bacterial culture, all but one of which were sensitive to an antibiotic. The majority of the 72 patients with negative microbial culture had received piperacillin/tazobactam $(\mathrm{n}=52,72.2 \%)$ compared with 25 of 132 culture positive patients (18.9\%). Other less common empiric antibiotics in culture negative patients were ceftriaxone $(\mathrm{n}=6,8.3 \%)$, vancomycin $(\mathrm{n}=5,6.9 \%)$, and cefuroxime $(\mathrm{n}=5,6.9 \%)$ (Figure 3).

Reviewing the antibiotic treatment for the 204 subjects, $150(73.5 \%)$ were treated with appropriate antibiotics, that is, they had received an antibiotic to which a bacterial isolate was sensitive. All but one of the 13 subjects with methicillin-resistant Staphylococcus aureus (MRSA) received vancomycin. One patient with MRSA received tigecycline. In 4 patients, extended spectrum beta-lactamases (ESBL) bacteria were cultured, for which ciprofloxacin (2 patients), meropenem (1 patient), and piperacillin/ tazobactam were appropriately administered (Figure 2).

Discussion. There is a paucity of studies regarding SSTIs among patients with solid tumors. We report an overall incidence of SSTI of 1.67\% among the patients presented to the Oncology Department over the course of 5 years. This rate is comparatively lower than a report from one study that reported a $69 \%$ prevalence of SSTI among cancer patients. ${ }^{2}$ A study carried out in 9 Asian countries reported that SSTIs were the most common types of infections in non-neutropenic cancer patients, accounting for $26.7 \%$ of the infections. ${ }^{14}$ This study focused only on Staphylococcus aureus infection appearing in cancer patients. The discrepancy in the rates of SSTs could also be attributed to differences in the study settings and designs. A retrospective 15 -month clinical study showed that $15 \%$ patients with X. maltophilia infection had SSTTs in a referral-based cancer centre. ${ }^{15}$ Approximately $7-10 \%$ of hospitalized patients are reported to experience SSTIs and they are common among patients in emergency department. ${ }^{12}$

In this study, exit site infections, also called catheterrelated bloodstream infections, were the most common SSTIs in patients with solid tumors. Other common SSTIs were wound infection, cellulitis, and abscess. These findings are consistent with previous reports. ${ }^{1}$ Most of the exit site infections have been reported to be caused by skin flora and can be treated successfully by topical or systemic antimicrobials. ${ }^{16}$ They can be prevented by using chlorhexidine-impregnated dressings and sponges and treated with topical antimicrobial agents based on culture results. ${ }^{17}$ For example, mupirocin ointment is commonly used for treating Staphylococcus aureus infection and ketoconazole or lotrimin ointment for Candida infection. ${ }^{18}$ 
Table 2 - Patients' characteristics.

\begin{tabular}{|c|c|}
\hline Variables & n $(\%)$ \\
\hline Female & $128(62.7)$ \\
\hline Mean age & $49.9(19.2)$ \\
\hline Mean weight & $61.7(10.2)$ \\
\hline Mean body mass index & $24(4.2)$ \\
\hline \multicolumn{2}{|l|}{ SSTI } \\
\hline $\begin{array}{l}\text { Exit site infection } \\
\text { Wound infection } \\
\text { Cellulitis } \\
\text { Abscess } \\
\text { Presence of fever } \\
\text { Previous invasive procedures } \\
\text { Recent chemotherapy } \\
\text { Diabetes } \\
\text { Recent radiotherapy } \\
\text { Previous transfusion } \\
\text { Appropriate antibiotics prescribed }\end{array}$ & $\begin{array}{c}84(41.2) \\
72(35.3) \\
44(21.5) \\
4(2.0) \\
163(80.0) \\
159(77.9) \\
155(76) \\
54(26.5) \\
21(10.3) \\
20(9.8) \\
150(73.5)\end{array}$ \\
\hline \multicolumn{2}{|l|}{ Antibiotics for culture negative infections $(n=72)$} \\
\hline $\begin{array}{l}\text { Piperacillin/tazobactam } \\
\text { Ceftriaxone } \\
\text { Vancomycin } \\
\text { Cefuroxime }\end{array}$ & $\begin{array}{c}52(72.2) \\
6(8.3) \\
5(6.9) \\
5(6.9)\end{array}$ \\
\hline \multicolumn{2}{|l|}{ Diabetes after chemotherapy } \\
\hline $\begin{array}{l}\text { No } \\
\text { Yes }\end{array}$ & $\begin{array}{l}133(65 \%) \\
71(35 \%)\end{array}$ \\
\hline \multicolumn{2}{|l|}{ Activity of chemotherapy } \\
\hline $\begin{array}{l}\text { Antimicotubules } \\
\text { Alkylating agents/antimicotubules } \\
\text { Antimetabolites } \\
\text { Antimetabolites/alkylating/antimicotubules } \\
\text { Antimicotubules/H2R } \\
\text { Others* }\end{array}$ & $\begin{array}{l}45(32.4) \\
18(12.9) \\
14(10.1) \\
13(9.4) \\
12(8.6) \\
37(26.6)\end{array}$ \\
\hline \multicolumn{2}{|l|}{ Types of chemotherapy } \\
\hline $\begin{array}{l}\text { Paclitaxel } \\
\text { Docetaxel } \\
\text { CHOP } \\
\text { FOLFOX } \\
\text { Paclitaxel/carboplatin } \\
\text { Others }^{\dagger}\end{array}$ & $\begin{array}{l}27(18.9) \\
21(14.7) \\
15(10.5) \\
13(9.1) \\
10(7.0) \\
57(39.9)\end{array}$ \\
\hline \multicolumn{2}{|l|}{ Frequency of chemotherapy } \\
\hline $\begin{array}{l}\text { Weekly } \\
\text { Every } 2 \text { weeks } \\
\text { Every } 3 \text { weeks } \\
\text { Monthly }\end{array}$ & $\begin{array}{c}51(37.0) \\
46(33.3) \\
40(29.0) \\
1(0.7)\end{array}$ \\
\hline \multicolumn{2}{|l|}{ Duration of chemotherapy } \\
\hline $\begin{array}{l}8 \text { cycles } \\
6 \text { cycles } \\
18 \text { cycles } \\
16 \text { cycles } \\
4 \text { cycles } \\
10 \text { cycles } \\
20 \text { cycles } \\
\text { Other cycles }\end{array}$ & $\begin{array}{c}22(15.8) \\
15(10.8) \\
12(8.6) \\
11(7.9) \\
9(6.5) \\
9(6.5) \\
8(5.8) \\
53(38.1)\end{array}$ \\
\hline \multicolumn{2}{|c|}{ 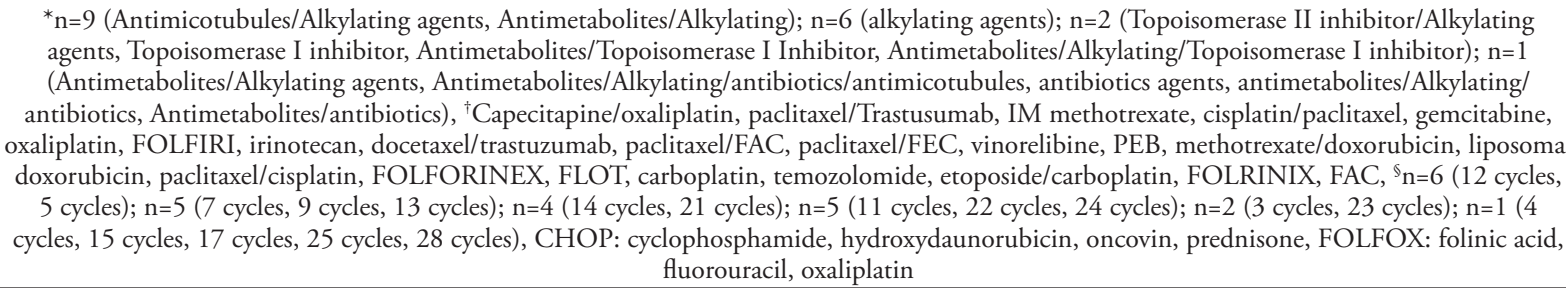 } \\
\hline
\end{tabular}


Infections in cancer patients ... Al-Mutairi et al

Table 3 - A comparison with the total number of patients with a specific tumour further classified by the type of SSTIs.

\begin{tabular}{|c|c|c|c|c|c|}
\hline Underlying malignancy & $\begin{array}{l}\text { Overall } \\
\mathrm{N}=204^{*}\end{array}$ & Abscess, $\mathrm{n}=4^{\dagger}$ & Cellulitis, $n=44^{\dagger}$ & Exist site infection, $\mathrm{n}=84^{\dagger}$ & Wound infection, $\mathrm{n}=72^{\dagger}$ \\
\hline & \multicolumn{5}{|c|}{ n (\%) } \\
\hline Adenocarcinoma & $3(1.5)$ & $0(0.0)$ & $1(33.3)$ & $0(0.0)$ & $2(66.7)$ \\
\hline Brain tumor & $2(1.0)$ & $0(0.0)$ & $0(0.0)$ & $2(100)$ & $0(0)$ \\
\hline Breast cancer & $78(38)$ & $2(3)$ & $14(18.0)$ & $33(42.0)$ & $29(37.0)$ \\
\hline Cervical cancer & $1(0.5)$ & $0(0.0)$ & $0(0.0)$ & $1(100)$ & $0(0.0)$ \\
\hline Cholangiocarcinoma & $2(1.0)$ & $0(0.0)$ & $0(0)$ & $2(100)$ & $0(0.0)$ \\
\hline Choriocarcinoma & $1(0.5)$ & $0(0.0)$ & $1(100)$ & $0(0.0)$ & $0(0.0)$ \\
\hline Colon cancer & $29(14)$ & $0(0.0)$ & $9(31)$ & $12(41.0)$ & $8(28.0)$ \\
\hline Rectal cancer & $4(2.0)$ & $0(0.0)$ & $0(0.0)$ & $2(50.0)$ & $2(50.0)$ \\
\hline Endometrial carcinoma & $1(0.5)$ & $0(0.0)$ & $1(100)$ & $0(0.0)$ & $0(0.0)$ \\
\hline Gastric cancer & $3(1.5)$ & $0(0.0)$ & $1(33.3)$ & $2(66.7)$ & $0(0.0)$ \\
\hline Gestational trophoblastic neoplasm & $4(2.0)$ & $0(0.0)$ & $1(25.0)$ & $3(75)$ & $0(0.0)$ \\
\hline Head and neck cancer & $1(0.5)$ & $0(0.0)$ & $0(0.0)$ & $1(100)$ & $0(0.0)$ \\
\hline Hepatocellular carcinoma & $4(2.0)$ & $0(0.0)$ & $0(0.0)$ & $0(0.0)$ & $4(100)$ \\
\hline Hodgkin lymphoma & $5(2.5)$ & $0(0.0)$ & $0(0.0)$ & $0(0.0)$ & $5(100)$ \\
\hline Leiomyosarcoma & $1(0.5)$ & $0(0.0)$ & $0(0.0)$ & $0(0.0)$ & $1(100)$ \\
\hline Liver cancer & $5(2.5)$ & $0(0.0)$ & $3(60)$ & $0(0.0)$ & $2(40.0)$ \\
\hline Lung cancer & $6(2.9)$ & $0(0.0)$ & $2(33)$ & $3(50.0)$ & $1(17.0)$ \\
\hline Lymphoma & $17(8.3)$ & $1(6.0)$ & $2(12)$ & $9(53.0)$ & $5(29.0)$ \\
\hline Malignant neoplasia of cervix & $1(0.5)$ & $0(0.0)$ & $1(100)$ & $0(0)$ & $0(0.0)$ \\
\hline Neuroendocrine tumour & $1(0.5)$ & $0(0.0)$ & $0(0.0)$ & $0(0)$ & $1(100)$ \\
\hline Oesophageal cancer & $3(1.5)$ & $1(33.3)$ & $0(0.0)$ & $1(33.3)$ & $1(33.3)$ \\
\hline Ovarian cancer & $13(6.4)$ & $0(0.0)$ & $2(15.0)$ & $4(31)$ & $7(54.0)$ \\
\hline Pancreatic cancer & $11(5.4)$ & $0(0.0)$ & $4(36.0)$ & $5(45.0)$ & $2(18.0)$ \\
\hline Prostate cancer & $1(0.5)$ & $0(0.0)$ & $0(0.0)$ & $0(0.0)$ & $1(100)$ \\
\hline Rectal carcinoma & $2(1.0)$ & $0(0.0)$ & $1(50.0)$ & $0(0.0)$ & $1(50)$ \\
\hline Seminoma & $4(2.0)$ & $0(0.0)$ & $1(25.0)$ & $3(75.0)$ & $0(0.0)$ \\
\hline Spindle cell sarcoma & $1(0.5)$ & $0(0.0)$ & $0(0.0)$ & $1(100)$ & $0(0.0)$ \\
\hline
\end{tabular}

n (\%): Patients with specific malignancy/total malignancy, ${ }^{\dagger} \mathrm{n}(\%)$ : Patients with specific malignancy/total malignancy, SSTI: soft-tissue infections

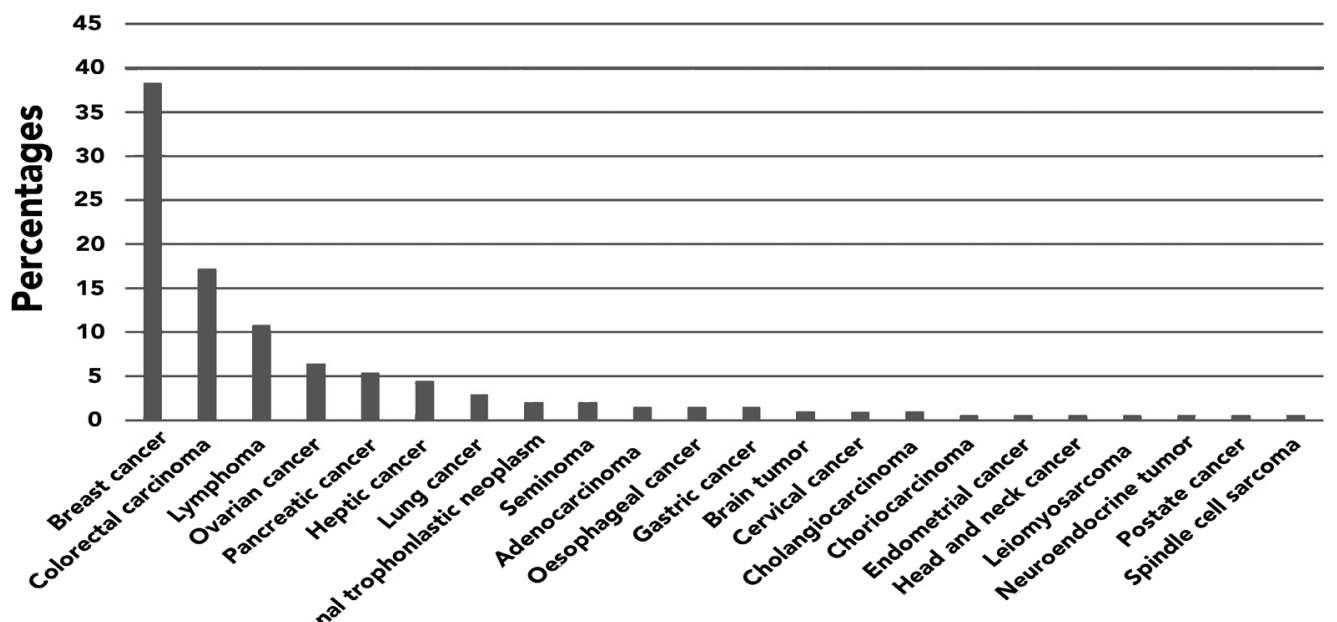

Underlying malignancy

Figure 1 - Percentage of cancers in patients with skin and soft tissue infections. 


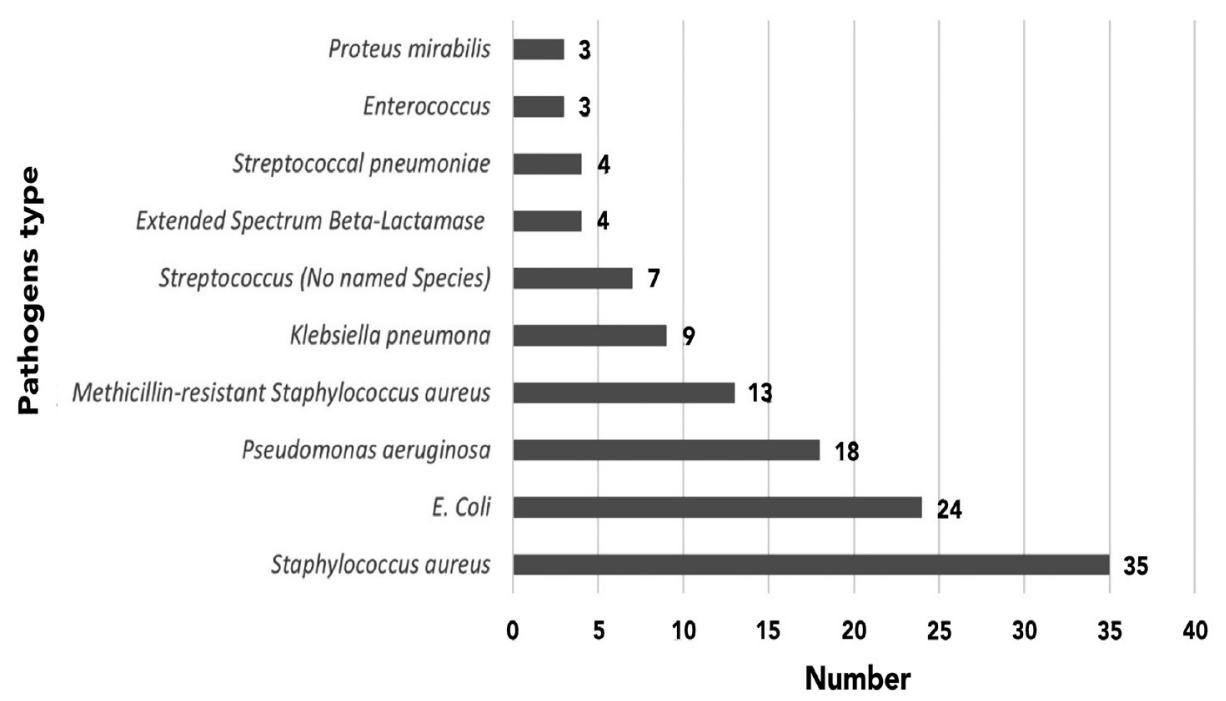

Figure 2 - Pathogens in blood culture.

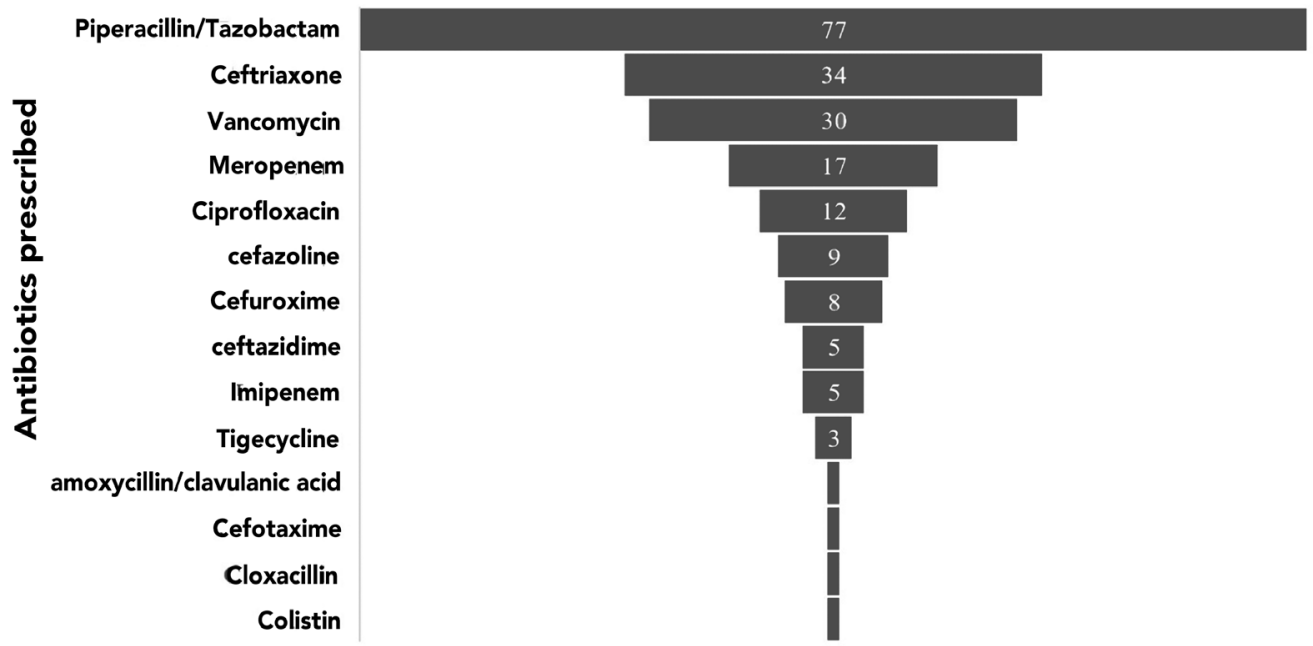

Figure 3 - Number of antibiotics prescribed for the treatment of skin and soft-tissue infections.

Staphylococcus aureus was the predominant pathogen in our study population, a finding similar to what has been reported in the United States and elsewhere. ${ }^{19}$ The preponderance of Staphylococcus aureus infection is associated with several challenges including recurrence and drug resistance. ${ }^{19}$ In one study, 39\% and 50\% of the patients with SSTI have recurrence of Staphylococcus aureus infection within 3 and 6 months, respectively. ${ }^{20}$ Furthermore, the emergence of multi-drug resistant Staphylococcus aureus isolates limit existing options for antimicrobial treatments. ${ }^{19}$ A 13 -years study also showed that Corynebacterium striatum, Corynebacterium amycolatum, and Macrobacterium species were the most common species isolated in paediatric oncology patients. $^{21}$

It is unclear from this study how the administration of chemotherapy and radiotherapy contributed to the onset and course of SSTIs. However, these treatments are established risk factors for the development of SSTIs in cancer patients. ${ }^{22}$ Similarly, some reports have shown that the use of chemotherapy and radiotherapy may have differential effects on the type of SSTI. ${ }^{23,24}$ For most patients in our center, the prescribed antibiotics were appropriate. 
In this study, the prescribing of antibiotics was appropriate in more than two-thirds of the patients. Piperacillin/tazobactam was the most prescribed antibiotic in SSTIs. Although Piperacillin/tazobactam have a broad-spectrum antibacterial activity, they are not recommended as first line agents to avert the emergence of resistant microorganisms. ${ }^{25}$ In our study, $80 \%$ of the cancer patients with SSTIs also had a fever. According to the Infectious Diseases Society of America guidelines, empiric antibacterial therapy with vancomycin plus cefepime, carbapenems or piperacillin-tazobactam is highly recommended in patients with SSTIs and fever. ${ }^{8}$

The evidence from this study may help facilitate a better understanding of the incidences and management of SSTIs in hospitalized cancer patients. This is particularly an issue as SSITs are associated with poor treatment outcome, which is a major contributor to morbidity and mortality.

However, there were some limitations to this study. First, this was a retrospective study, therefore, we did not have sufficient information regarding some of the variables of interest. Secondly, this study was conducted at a single healthcare setting in the KSA, thus the findings cannot be generalized to the entire Saudi population. The risk factors associated with SSTIs in cancer patients are worth further investigation. Moreover, large multicentre studies are needed for a more generalizable knowledge of SSTIs in cancer patients in Saudi Arabia.

In conclusion, this study has shown a modest incidence of SSTIs in hospitalized cancer patients. Exit site infection was prevalent, with Staphylococcus aureus being the most common pathogen. Appropriate antibiotics were prescribed in many cancer patients with SSTIs. Large studies are needed to validate our findings, and to ascertain whether appropriate initial antibiotic treatment will improve outcomes for hospitalized cancer patients with SSTIs.

\section{References}

1. Kofteridis DP, Valachis A, Koutsounaki E, Maraki S, Mavrogeni E, Economidou FN, et al. Skin and soft tissue infections in patients with solid tumours. Sci World J 2012; 2012: 804518.

2. Szvalb AD, Rolston KVI, editors. Skin and Soft Tissue Infections Among Cancer Patients. Springer International Publishing; 2020. p. 1465-76.

3. May AK. Skin and soft tissue infections. Surg Clin North Am 2009; 89: 403-420.

4. Sartelli M, Guirao X, Hardcastle TC, Kluger Y, Boermeester MA, Raşa K, et al. 2018 WSES/SIS-E consensus conference: recommendations for the management of skin and soft-tissue infections. World J Emerg Surg 2018; 13: 58.

5. Ustin JS, Malangoni MA. Necrotizing soft-tissue infections. Infect Dis Clin North Am 2021; 35: 135-155.
6. Lopez FA, Sanders CV. Dermatologic infections in the immunocompromised (non-HIV) host. Infect Dis Clin North Am 2001; 15: 671-702.

7. Pizzo PA, Meyers J, Freifeld AG, Walsh T. Infection in the cancer patient. In: DeVita VT, Hellman S, Rosenberg S, editors. Cancer Principle and Practice of Oncology. 8th edition. Philadelphia, Pa (USA): Lippincot Company; 2009. pp. 2292-2337. Available from https://books.google.com.au/books ?hl=en\&lr=\&id=yrBI5zx69X8C\&oi=fnd\&pg=PA1487\&ots=R c7oxVfPMm\&sig=IgceltUu9oWxakg9z1Ixlm_Ux_U\&redir_ esc $=\mathrm{y} \# \mathrm{v}=$ onepage $\& \mathrm{q} \& \mathrm{f}=$ false 8 . Stevens DL, Bisno AL, Chambers HF, Dellinger EP, Goldstein EJ, Gorbach SL, et al. Practice guidelines for the diagnosis and management of skin and soft tissue infections: 2014 update by the Infectious Diseases Society of America. Clin Infect Dis 2014; 59: e10-e52.

9. Paydar KZ, Hansen SL, Charlebois ED, Harris HW, Young DM. Inappropriate antibiotic use in soft tissue infections. Arch Surg 2006; 141: 850-854; discussion 855-6.

10. Khan S, Dhadda A, Fyfe D, Sundar S. Impact of neutropenia on delivering planned chemotherapy for solid tumours. Eur J Cancer Care (Engl) 2008; 17: 19-25.

11. Chathuranga G, Dissanayake T, Fernando N, Wanigatunge C. Appropriateness of the empirical antibiotics prescribed and their concordance with National Guidelines for three selected infections among cancer patients in a tertiary care centre in Sri Lanka. Int J Microbiol 2021; 2021: 7572215.

12. Ki V, Rotstein C. Bacterial skin and soft tissue infections in adults: A review of their epidemiology, pathogenesis, diagnosis, treatment and site of care. Can J Infect Dis Med Microbiol 2008; 19: 173-184.

13. National Cancer Institute. Common Toxicity Criteria (NCICTC) v2.0 1999. [Updated 1999; Accessed 2021 Sept 02]. Available from: https://ctep.cancer.gov/protocolDevelopment/ electronic_applications/docs/ctcv20_4-30-992.pdf.

14. Kang CI, Song JH, Ko KS, Chung DR, Peck KR, Asian Network for Surveillance of Resistant Pathogens Study G. Clinical features and outcomes of Staphylococcus aureus infections in non-neutropenic cancer patients. Support Care Cancer 2012; 20: 483-488.

15. Vartivarian SE, Papadakis KA, Palacios JA, Manning JT, Anaissie EJ. Mucocutaneous and soft tissue infections caused by Xanthomonas maltophilia: a new spectrum. Ann Intern Med 1994; 121: 969-973.

16. Yap DYH, Yip T, editors. Diagnosis and Management of Exit Site Infection in Peritoneal Dialysis Patients. InTech; 2016.

17. Queensland Government. Tunnelled Central Venous Catheters. [Updated 2018; Accessed 2021 Aug 15]. Available from: https:// www.health.qld.gov.au/_data/assets/pdf_file/0031/444487/ icare-tcvc-guideline.pdf

18. Mermel LA, Allon M, Bouza E, Craven DE, Flynn P, O’Grady NP, et al. Clinical practice guidelines for the diagnosis and management of intravascular catheter-related infection: 2009 Update by the Infectious Diseases Society of America. Clin Infect Dis 2009; 49: 1-45.

19. Montgomery CP, David MZ, Daum RS. Host factors that contribute to recurrent staphylococcal skin infection. Curr Opin Infect Dis 2015; 28: 253-258.

20. Miller LG, Eells SJ, David MZ, Ortiz N, Taylor AR, Kumar N, et al. Staphylococcus aureus skin infection recurrences among household members: an examination of host, behavioral, and pathogen-level predictors. Clin Infect Dis 2015; 60: 753-763. 
21. Adderson EE, Boudreaux JW, Hayden RT. Infections caused by coryneform bacteria in pediatric oncology patients. Pediatr Infect Dis J 2008; 27: 136-141.

22. Scanlon MM, Gazelka HM, Moeschler SM, Hoelzer BC, Hooten WM, Bendel MA, et al. Surgical site infections in cancer patients with intrathecal drug delivery devices. Pain Med 2017; 18: 520-525.

23. Lawson EH, Hall BL, Ko CY. Risk factors for superficial vs deep/ organ-space surgical site infections: implications for quality improvement initiatives. JAMA Surg 2013; 148: 849-858.
24. Lieber BA, Appelboom G, Taylor BE, Lowy FD, Bruce EM, Sonabend AM, et al. Preoperative chemotherapy and corticosteroids: independent predictors of cranial surgical-site infections. J Neurosurg 2016; 125: 187-195.

25. Takimoto K, Wang Q, Suzuki D, Katayama M, Hayashi Y. Clinical efficacy of piperacillin/tazobactam in the treatment of complicated skin and soft tissue infections. Expert Opin Pharmacother 2017; 18: 1027-1034. 